\title{
The State of Security Law Violations by the Private Security Businesses in Seoul and Countermeasures
}

\author{
Dr. Ju-lak Lee (Corresponding author) \\ South Korea \\ Email: julaklee@kyonggi.ac.kr \\ Seok Lee, Ph D. Candidate \\ Department of Security Management \\ Kyonggi University, South Korea \\ Jinsung Kim, Ph D. Candidate \\ Department of Security Management \\ Kyonggi University, South Korea
}

Associate Professor, Department of Security Management, Kyonggi University

Accepted: July 08, 2014

Doi:10.5296/ jpag.v4i3.6155 URL: http://dx.doi.org/10.5296/ jpag.v4i3.6155

\begin{abstract}
The private security industry in South Korea has grown rapidly since the cessation of the Korean War in 1953. The main duty of the private security officers in their beginning era was to simply protect the supplies of the U.S. military stationed in the country, but the number of people employed in the business has outgrown the number of police officers since 2001.

Despite the quantitative development of the private security industry, the quality of the services provided by the businesses has not advanced sufficiently except for a few number of specialized areas because of the perception that the police should be in charge of the overall security of society in addition to the low crime rate in the country and the lack of safety awareness by citizens. This has also resulted in an overflow of under-qualified businesses. Moreover, the lack of sense of duty among the employees of private security has resulted in violations of the existing laws and regulations, which has hindered further development of the industry. In this study, the current state of the private security companies registered at the Seoul Metropolitan Police Agency is examined in addition to the details of the Private Security Act and its breaches by the security businesses in Seoul area during 2013. With a
\end{abstract}


basis on the findings, the causes for the violations are assessed and prevention measures are suggested.

Keywords: Private Security Act, Security Act, Violation of Law, South Korea, Seoul

\section{Introduction}

The private security industry in South Korea began in 1953 as the management force for the supplies of the U.S. military stationed in South Korea. Then its work expanded to ensuring the security of temporary petroleum storages around harbors. As in the case of other countries, the demand for private security services rose in the areas that could not be reached by public sectors.

The Act for the Policemen on the Special Guard Assignment and the Security Act which passed in 1973 and 1976, respectively laid the foundation for the laws for private security acts. These laws were developed significantly as the country hosted different international events including the 1986 Asian Games, 1988 Seoul Olympic Games, and 2002 World Cup. In 2001, the number of private security officers exceeded that of the police officers (Lim, 2008).

However, despite the quantitative development of the private security industry, it provides services only in specialized areas because of the perception that the police should be in charge of the overall security of society in addition to the low crime rate in the country and the lack of safety awareness by citizens. This has resulted in an overflow of under-qualified businesses (Kwon, 2006). Moreover, the lack of sense of duty among the employees of private security has resulted in violations of the existing laws and regulations, which has hindered further development of the industry (Park, 2007).

In this study, the state of the private security providers that are registered at the Seoul Metropolitan Police Agency are investigated. Additionally, violations of the Security Act by these companies during 2013 are examined. Finally, the causes of law breaches and countermeasures are discussed.

\section{Current State of Security Industry}

In order to help understand the present state of the security industry in South Korea, following statistics of 2013 are presented. 
Table 1. Number of Private Security Businesses by Employee Size

\begin{tabular}{llllllll}
\hline Total & 10 or Less & $11 \sim 20$ & $21 \sim 30$ & $31 \sim 100$ & $\begin{array}{l}101 \sim \\
200\end{array}$ & $\begin{array}{l}201 \sim \\
1000\end{array}$ & or More \\
\hline 4,077 & 2,597 & 499 & 237 & 440 & 150 & 141 & 13 \\
\hline
\end{tabular}

Korea National Police Agency, 2014.

Table 2. Approved Service Types

\begin{tabular}{llllll}
\hline Total & $\begin{array}{l}\text { Facility } \\
\text { Security }\end{array}$ & Escort & $\begin{array}{l}\text { Personal } \\
\text { Protection }\end{array}$ & $\begin{array}{l}\text { Electronic } \\
\text { Security }\end{array}$ & $\begin{array}{l}\text { Special } \\
\text { Security }\end{array}$ \\
\hline 4,822 & 3,971 & 42 & 515 & 145 & 139 \\
\hline
\end{tabular}

$※ 745$ of the 4,077 businesses provide multiple approved services

Korea National Police Agency, 2014.

Table 3. Age of Security Officers

\begin{tabular}{lllllll}
\hline Total & $20 \mathrm{~s}$ & $30 \mathrm{~s}$ & $40 \mathrm{~s}$ & $50 \mathrm{~s}$ & $60 \mathrm{~s}$ & $70 \mathrm{~s}$ \\
\hline 151,741 & 23,074 & 19,674 & 11,964 & 24,312 & 51,304 & 21,413 \\
\hline
\end{tabular}

Korea National Police Agency, 2014.

As shown by the statistics, eighty-two percent of the security businesses is concentrated on facility security and less than one percent provides escort services. Furthermore, Sixty-three percent has ten or less employees and 92.5 percent of the companies are comprised of 100 or less workers.

In sum, the most security officers in South Korea are employed to protect facilities, which does not require specialized skills or experiences. In addition, a large number of elderly employees raises a concern that they may not be suitable examples of active and agile security individuals to carry out the tasks. 


\section{Macrothink \\ Journal of Public Administration and Governance \\ ISSN 2161-7104 \\ 2014, Vol. 4, No. 3}

\section{Administrative Measures for Violations of Security Act ${ }^{1}$}

\subsection{Administrative Measures}

\subsubsection{Person in Charge}

Commissioner of the metropolitan police agency whose jurisdiction covers the location of the security business headquarters

\subsubsection{Type}

- Revocation of business license: Cancels the approval of the business for the applicable year and retrieves the license.

- Suspension of business license: A full or a partial suspension of business for six months. Specifically, a partial suspension means that a business may be suspended in only one of the locations in which it provides services, and it may receive suspension for only the type of work for which it has violated the laws.

\subsubsection{Mandatory License Revocation}

The Section 1, Clause 19 of the Security Act states that the following cases must be responded with mandatory license revocation.

- When a business obtains a fake license or a license illegitimately

- When a business employs a security officer to work on other than security-related tasks.

- When a business provide non-security services.

- When a business does not have actual history of work or halts its business for one year or longer.

- When a business does not acquire a new contract within one year from the termination of the current one.

- When a business continues its work after being suspended.

- When a business does not abide by the order of the head of the supervisory police agency to withdraw the assignments of security officers.

\subsubsection{Suspension or business or license revocation}

Section 2, Clause 19 of the Security Act states that the following cases will be responded with a suspension of six-month or less or revocation of license; it is a discretional decision.

- Change of tasks without permission of the head of the supervisory police agency: Related to Clause 4 of the Act which states that warning and suspension will be given for first and

\footnotetext{
${ }^{1}$ Lee, S. H. (2013). The assessment and political subject of Revised Security Industry Law, Korean
} security science review, 36: 349-386. 
second violation, respectively. For the third violation, a business can lose its license.

- Failure to refuse the unlawful security service requests: Section 2, Clause 7 of the Act states that first and second violations lead to one- and three-month suspension, respectively, and third violation results in license revocation.

- Employment of under-qualified security instructors or officers: Section 3, Clause 10 states that first and second violations lead to one- and three-month suspension, respectively, and third violation results in license revocation.

- Assignment of an under-qualified security instructor: Section 1, Clause 12 states that same administrative penalties apply as in the case of employment of under-qualified security officers.

- Failure to provide training sessions to new or existing security officers: A penalty related to Clause 13 states that first and second violations are dealt with warnings and third violation results in one-month suspension.

- Violations related to the uniform and equipment of security officers and vehicles: Clause 16 states that first and second violations are dealt with warnings and third violation results in one-month suspension.

- Non-fulfillment of the orders given by the head of the supervising police agency: Clause 24 states that first violation is dealt with a warning, second results in a three-month suspension, and third leads to license revocation.

- Failure to compensate the costs incurred while performing the tasks: Related Clause 26 states that first violation is dealt with a warning, second results in a three-month suspension, and third may result in six-month suspension.

- Following is a new list of violation and does not have stages of applicable penalties.

- Failure to assign/dispatch a security instructor at the site of public grievance.

- Failure to install alarm systems on the targeted facilities

- Failure to display response-related documents

- Failure to display a roster of security officers at the site of public grievance.

- Dispatching security officers without permission or applying for false dispatch permission

- Dispatching disqualified security officers at the site of public grievance 
3.1.5 State of administrative penalties

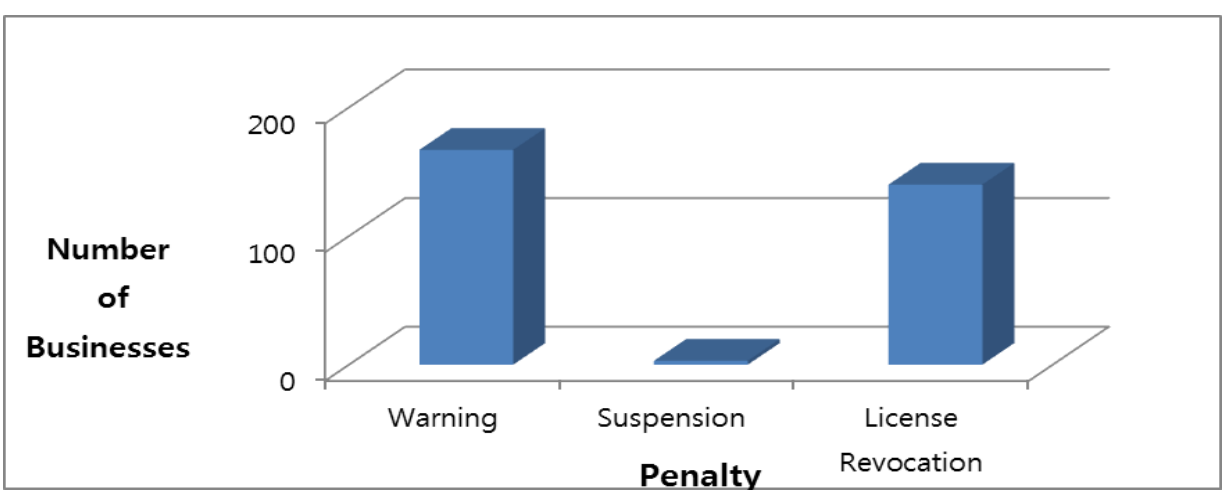

Figure 1. By Penalty Type.

Seoul Metropolitan Police Agency, 2014.

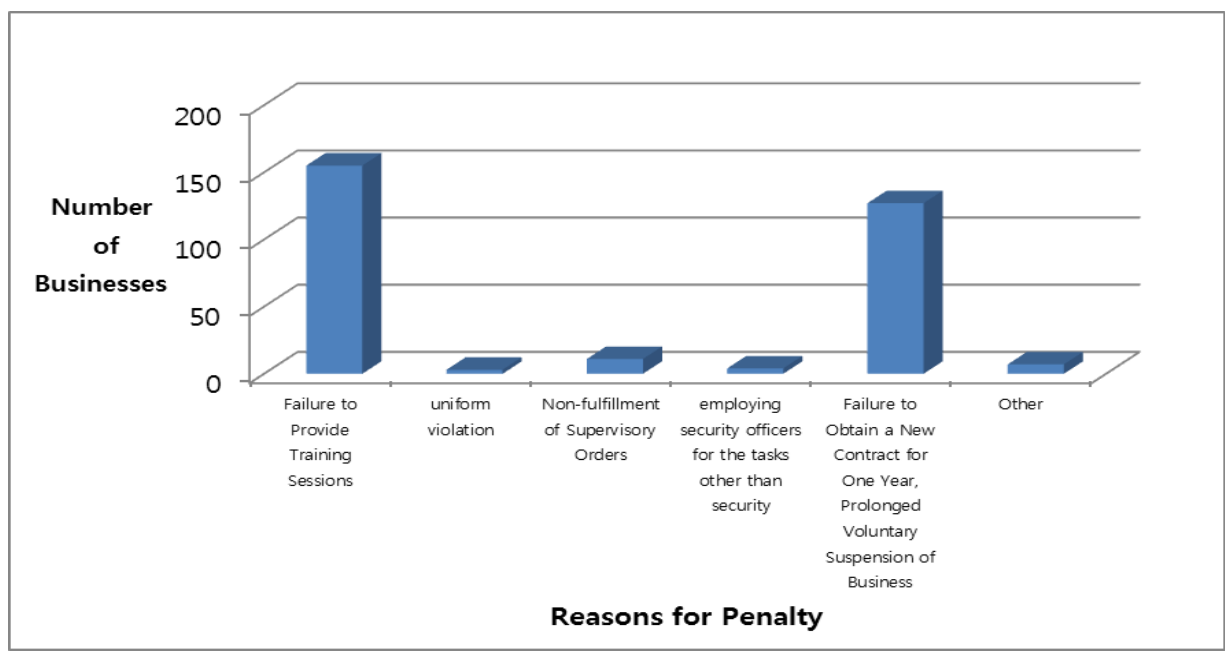

Figure 2. Administrative Penalty

Seoul Metropolitan Police Agency, 2014.

The tables above show the state of administrative penalties given during 2013. Warning is the most common type of penalty (167cases), followed by license revocation (140 cases) and suspension ( 3 cases).

When the administrative penalties are analyzed by type of violation, fifty-percent of the violations are failure to provide required training sessions to the employees (i.e. four-

hour and six-hour monthly training for general and special officers, respectively as stated in Clause 13 of the Act).

Next most common violation is failure to obtain a contract for a year or prolonged voluntary 


\section{Macrothink}

business suspension. This has resulted from a growing number of security businesses with limited demand for their services. Other reasons for penalties include non-fulfillment of supervisory orders, employing security officers for the tasks other than security, uniform violation, ect.

\subsection{Fine $^{2}$}

\subsubsection{Collector}

Commissioner of a metropolitan agency or chief of a police station

\subsubsection{Target}

Owner of security business or national facility

\subsubsection{Process}

- After an investigation and confirmation stage, a police agency should provide a ten-day period for the business owner to submit an opinion.

- A written statement and a bill must be sent out to the violator.

- Submission of opinion: Within sixty days of receiving a notification, a written opinion can be submitted.

\subsubsection{Reasons for imposing fines and amount}

- Based on Section 1, Clause 31 of the Security Act, below violations are handled with a fine of thirty-million won or less.

- Failure to report on the uniform violation of security officers and dispatching the officers at the site of civil appeal.

- Dispatching officers without name tags or in the uniforms different from those reported to the site of civil appeal.

- Failure to display a roster of dispatched officers at the site of civil appeal

- Dispatching officers without permission or applying for false dispatch permission

- Dispatching officers without proper training to the site of civil appeal or as special officers.

- Fines are imposed upon the following cases as per Section 2, Clause 31 of the Act.

\footnotetext{
2 Park, B. S. (2011). Problems of Security Act and Solutions, Korean security science review, 29: 89-113.
} 


\section{Macrothink}

- When a business violates Section 3, Clause 4 (voluntary suspension, closedown, etc.) or Section 2, Clause 18 (dispatch, shutdown, etc.), fines are imposed according to the length of violation: one million won for one to six months, two million won for six to twelve months, three million won for over twelve months.

- In the case of a failure to report as the designated security service provider for national facilities, four- and three-million won is imposed for false report and not reporting for other reasons, respectively.

- One-million won is imposed for violation of the explanation duty of Section 1, Clause 9, three-million won for not hiring a security instructor (violation of Section 1, Clause 12), five-million won for not carrying out the order of the supervisory agency (violation of Section 6, Clause 14), and one-million won for not creating/displaying the roster of dispatched officers (violation of Section 1, Clause 18).

\subsubsection{State of Fine Imposition}

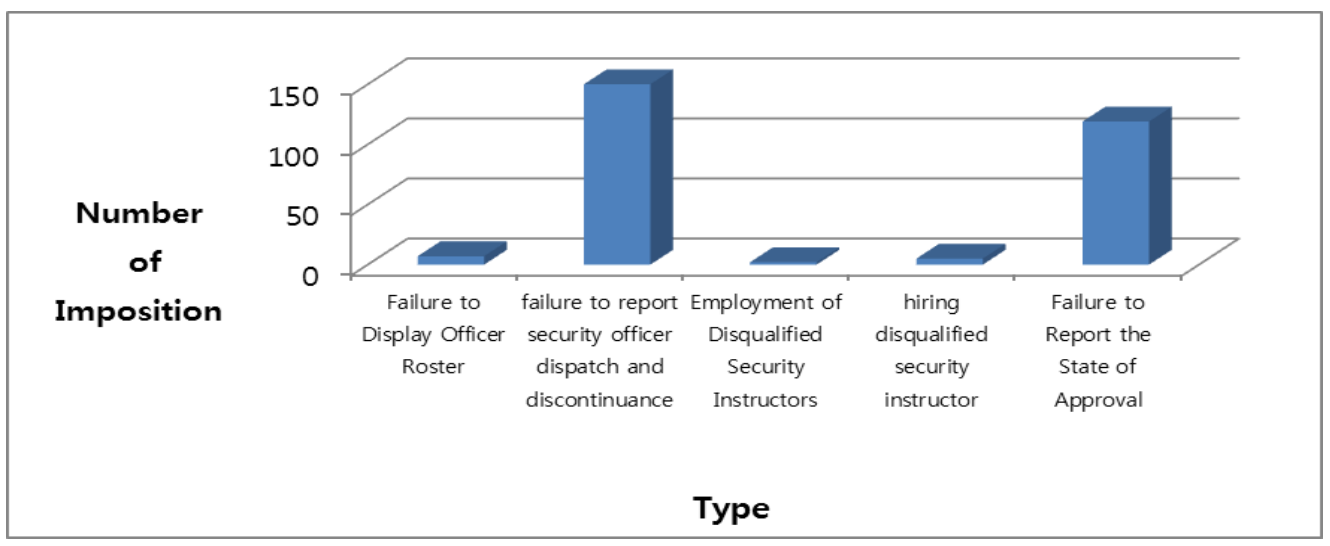

Figure 3. State of Fine Imposition

Seoul Metropolitan Police Agency, 2014

The most common violation for fine is failure to report security officer dispatch and discontinuance (150 cases); high turnover rates and the short period to report dispatch and discontinuance (seven days) seem to have contributed to the high frequency of violation. Also, 119 cases of failing to report the state of approval, especially the change of executives and memorandum of association. Moreover, failing to display officer roster and hiring disqualified security instructor are other reasons for fines. 


\section{MInstitute"}

\section{Problem}

\subsection{A large number of service providers due to the low certification standard}

After the revision of the Security Act, the requirements to establish a security business has become more strict since June 8, 2014. Still, only fifty-million won is needed to obtain the permission to found a security business except for specialized security. Therefore, numerous under-qualified companies receive permissions to provide services, which lead to non-fulfillment of even the basic requirements stated in the Act. As a result, it hinders the growth and ensuring the order of the security industry(Park, 2013).

\subsection{Ignorance about the Act}

The fact that a business can obtain contracts through various networking and nepotism, security companies generally disregard the existing laws and violate them on a regular basis(Lee, 2013).

\subsection{Need to utilize security instructors systematically}

In an effort to reduce costs, security businesses tend to appoint professional security instructors instead of hiring them full-time. As a result, regular tasks such as officer training, inspection of dispatch locations, and completing documents are not carried out properly and the relevant laws are violated frequently (Kim, 2012).

\subsection{Insufficient education and supervision by police}

Supervision and management of the security businesses by the police, the supervising organization, is quite insufficient. Although inspections on the security companies are conducted twice every year, it is impossible to perform the task thoroughly on over four-thousand businesses. Additionally, the police officers assigned to this duty are often in charge of other work so they typically cannot invest much time on it. Furthermore, in cases of personnel change, new police officers may not have adequate knowledge to fulfill the duty successfully (Choe, 2012).

\subsection{Need for a better department in charge}

The private security industry in South Korea, the basis for private security officer system, is supported by the government as an emerging professional field. It has advanced for about fifty years. In its early days, security businesses specialized in protecting the supplies of the U.S. military and petroleum storages. Today, the industry has grown so more than four thousand security businesses provide services with over 150 thousand employees (Kim, 2009). Despite its potential for additional development, there needs to be an adequate supervisory department in the police. Currently, the cooperation safety team of the public safety division at the public safety bureau takes charge of managing the private security industry. However, there are countless other duties that the police officers of this team need to perform on a regular basis(Kim, 2013). 


\section{Measure}

\subsection{Reinforcement of training and promotion for private security industry}

It is necessary to provide regular training for new and existing security businesses and distribute the brochures to inform them of the relevant laws to minimize violations.

\subsection{Structured regulation and inspection by the supervising agency}

Korean National Police Agency, the supervising organization, aims to inspect the security businesses' observance of the laws twice a year; and Korean National Police Agency entrusts the police stations of each jurisdiction to carry out the duty. Specifically, in order to increase the accuracy and minimize corruption, each responsible officer is paired with another officer from a nearby police station. When this is not viable, the leader of the public safety team at the police station in charge in addition to two or more officers perform the task. Unfortunately, there are instances in which one police station must oversee nearly fifty security businesses so proper supervision is difficult. Therefore, most security businesses are not concerned about their violations being exposed and they may even offer bribery to the officers.

In order to improve this problem, some have suggested the autonomous inspection system. However, as shown by the Sewol ferry disaster, entrusting private entities to perform safety inspections could result in national disasters. Therefore, Korean National Police Agency should develop and utilize a checklist for consistent and prompt inspection. In addition, police stations should dispatch their officers more flexibly to support the inspection task.

\subsection{Reinforcement of the role of security instructor}

According to the law, one security instructor must be assigned when 200 or more officers are dispatched. This should be reinforced so security duties can be carried out and the laws are observed more strictly.

\subsection{Improved communication between the police and the security industry}

To achieve realistic legal improvement and obtain accurate information on the current state of the industry, communication between the police and the security industry must be encouraged. In order to understand the issues of the industry, constant communication must be promoted by the supervisory organization, the police, at a profound level. The industry should also be proactive in communicating with the police.

\section{Conclusion}

The private security industry of South Korea, established to support the work of the police, has more than a sixty-year of history. Although its primary duties included facility protection and physical security, the businesses started to provide electronic security, escort, and special security with the development in science and various societal demand for security (Kim, 2009). Specifically, the advancement in information communication technologies affected the private security industry in South Korea significantly, which promoted it to support and cooperate with the public sector to prevent crimes and establish societal safety networks 
(Park, 2006).

Despite the qualitative and quantitative development, the lack of understanding about the Security Act, insufficient interest by the supervisory organization (i.e. Korean National Police Agency), and law violations by small-size businesses are hindering further advancement. Observance of relevant regulations must be encouraged to achieve additional development of the industry.

To foster observance of the laws, Korean National Police Agency must create such environment. Regular training sessions targeting new and existing businesses need to be provided to inform them of the relevant laws. Also, for the companies that violate the laws, administrative penalties must be imposed strictly to benefit the law-abiding businesses.

Furthermore, the system for security instructors must be activated to raise the level of private security work. Lastly, Korean National Police Agency and the private security industry should communicate more extensively; through this process, cooperation between the two parties can be promoted. In addition, as seen in the case of Sewol disaster, despite the desire of the industry, entrusting the private sector to supervise the security businesses does not seem like a viable option.

\section{References}

Choe, S. O. (2012). A study on the problems of an office scope of security law and reform measures. Korean Law Review, 48, 99-117

Kim, C. H. (2009). A Study on Private Security: Focusing on Revision of the Private Security Law. Public land Law Review, 43(2), 565-585

Kim, N. J. (2012). Improvement of Private Security Fallowing in Development of Korea Security Service. Journal of the Korean society private security, 11(2), 3-25

Kim, T. M. (2013). A Study on the Effective Law Revision for Private Security Industry. Journal of Korean public police and security studies, 10(1), 123-144

Kim, T. M. (2009). The Problems and Improvement Measures of Private Security Industry in Korea. The Korean Association of Police Science Review, 20, 37-65

Kwon, S. R. (2006). A Study on the Current Status and Development Plan of Private Security Industry. Korean Law Review, 22, 443-464

Lee, S. H. (2013). The assessment and political subject of Revised Security Industry Law. Korean security science review, 36, 349-386

Lee, S. H. (2013). Iagnosis of the private security industry law and development direction for the coordination of police and private security. Korean Journal of Public Safety and Criminal Justice, 53, 164-192

Lim, M. S. (2008). The Current Status of Korea's Private Guard Service Industry and Problems and Suggestions on the Guard Business Law. Journal of the Korean society private security, 11, 99-121 


\section{Macrothink}

Journal of Public Administration and Governance ISSN 2161-7104 2014, Vol. 4, No. 3

Park, B. S. (2011). Problems of Security Act and Solutions. Korean security science review, $29,89-113$

Park, H. S. (2013). A Study on The Problem of The Revised Security Industry Law and Improvement Plan. Convergence security journal, 13(5), 129-135

Park, J. S. (2007). A Study for the Introduction plan about Private Security and Professional Qualification System. Journal of the Korean society private security, 9, 63-115

Park, O. C. (2006). A Study on Developing Professional Training of the Private Security Industry. Korean Society of Disaster Information Review, 2(1), 91-111 